\title{
Molecular detection methods developed for a systemic rickettsia-like bacterium (RLB) in Penaeus monodon (Decapoda: Crustacea)
}

\author{
Linda M. Nunan ${ }^{1, *}$, Bonnie Poulos ${ }^{1}$, Rita Redman ${ }^{1}$, Marc Le Groumellec $^{2}$, \\ Donald V. Lightner ${ }^{1}$ \\ ${ }^{1}$ Department of Veterinary Sciences and Microbiology, University of Arizona, Tucson, Arizona 85721, USA \\ ${ }^{2}$ AQUALMA, Aquaculture de la Mahajamba, Mahajanga 401, Madagascar
}

\begin{abstract}
Molecular detection methods were developed to aid in the diagnosis of a rickettsia-like bacterium (RLB) which caused severe mortalities of farm-raised Penaeus monodon in Madagascar. Using primers derived from the 16S rRNA gene of bacteria, a PCR assay was optimized to amplify this region of the genome of the RLB, using extracted DNA from infected P. monodon tissue as the template. The resulting amplified PCR product was sequenced and 2 novel primers were selected from the variable region of the gene. These primers amplified a $532 \mathrm{bp}$ fragment of DNA originating from the rickettsia-infected samples. The PCR assay was optimized and tested on DNA extracted from specific pathogen-free (SPF) $P$. vannamei tissue and several other strains of bacteria. The PCR assay with the rickettsia-specific primers was specific for this RLB and did not amplify the other DNA samples tested. The 532 bp PCR-amplified fragment was labeled with digoxigenin (DIG) for in situ hybridization assays. This probe was tested on SPF, RLB and bacteria-infected shrimp specimens preserved in Davidson's fixative. The probe was specific for both natural and experimental rickettsial infections. Hybridization with this probe required a stringent temperature of $65^{\circ} \mathrm{C}$, otherwise cross-reactivity was observed with other types of bacteria.
\end{abstract}

KEY WORDS: Rickettsia $\cdot$ Penaeus monodon $\cdot$ Shrimp $\cdot$ Crustacea

\section{INTRODUCTION}

Severe mortalities of commercially farmed Penaeus monodon in grow-out ponds occurred due to a rickettsia-like bacterium (RLB) during the fall of 1999 in the SW region of Madagascar. Stocking density of the 6 ponds in which the mortalities were observed was $14 \mathrm{~m}^{-2}$ with no aeration. Mortalities were observed after $86 \mathrm{~d}$ (10 October) of culture, when shrimp weighed $5 \mathrm{~g}$, and increased considerably at $110 \mathrm{~d}$ (between 5 and 18 November) when the shrimp had reached $12 \mathrm{~g}$.

Clinical signs of diagnostic significance included shell necrosis of moribund shrimp with calcium precipitated on the surface of the cephalothorax. Moribund shrimp, in the pre-molt stage, were characterized by whitish hepatopancreas tissues, although no atrophy was observed. In addition, drawn hemolymph from affected shrimp failed to clot.

Rickettsia are gram-negative, obligate intracellular pathogenic bacteria that grow only within the cytoplasm, and occasionally the nucleus, of eucaryotic cells (Frutos et al. 1994). The pathology of rickettsial infections result from host-cell destruction. To survive and reproduce, the rickettsia organism must enter the eucaryotic host cell, multiply within the cell, exit and reestablish this cycle in another cell (Winkler 1990). Rickettsia-like microorganisms infect a wide range of aquatic crustaceans including amphipods, crabs, freshwater crayfish and prawns (Federici et al. 1974, Harshbarger et al. 1977, Bonami \& Pappalardo 1980, Larrson 1982, Johnson 1984, Brock et al. 1986, Anderson et al. 1987, Krol et al. 1991, Frelier et al. 1992, Fryer \& Lan- 
nan 1994, Bower et al. 1996, Jimenez \& Romero 1997, Edgerton \& Prior 1999, Wang \& Gu 2002).

This study presents 2 molecular methods, PCR and in situ hybridization assays, developed specifically for the detection of the rickettsia of Penaeus monodon from Madagascar. Both molecular techniques were designed to recognize the $16 \mathrm{~S}$ rRNA region of the bacterium.

\section{MATERIALS AND METHODS}

Identification of pathogen. Samples of Penaeus monodon from ponds sustaining daily mortalities were preserved in Davidson's AFA fixative (Bell \& Lightner 1988) for histopathological examination. Tissues embedded in ParaPlast Plus paraffin (Fisher Scientific) were sectioned at $4 \mu \mathrm{m}$ thickness, mounted onto microscope slides, deparaffinized and stained with either haematoxylin and eosin (Lightner 1996) or GramTwort stain (Ollett 1947). Histological examination of the processed samples was performed using standard light microscopy. Histological terms used follow Bell \& Lightner (1988) and shrimp taxonomy is according to Holthuis (1980).

No tissues from Penaeus monodon were preserved using standard fixatives for transmission electron microscopy (TEM); therefore, for TEM, tissue samples were recovered from those initially preserved in Davidson's fixative. Selected tissue blocks were deparaffinized in xylene and rehydrated through graded alcohols for post-fixation in $1 \%$ phosphate buffered osmium tetroxide. Tissues were then dehydrated, embedded in Spurr's epoxy resin (Ladd Research), and thin-sectioned. Thin-sections mounted on copper grids and stained with uranyl acetate and lead citrate were examined with a Joel 100CX II electron microscope operated at $80 \mathrm{kV}$.

Infectivity in Penaeus vannamei. Specific pathogenfree (SPF) juvenile (3 g) $P$. vannamei were injected in the third abdominal segment with a tissue homogenate prepared from $P$. monodon naturally infected with the Madagascar rickettsia. The shrimp were observed daily for signs of disease. Moribund shrimp were either preserved in Davidson's fixative for histological examination and in situ hybridization assays or frozen for PCR analysis. Moribund shrimp were observed at $5 \mathrm{~d}$ post-injection (p.i.) and mortalities continued until the experiment was terminated after 21 d (p.i.).

Rickettsial isolate and DNA extraction. Frozen rickettsia tissue for the development of PCR and in situ hybridization assays was obtained from a farm in Madagascar that had sustained daily Peneaus monodon mortalities. The method for purification of the bacteria was adapted from Tan \& Owens (2000). Briefly, $12.5 \mathrm{~g}$ of cephalothorax tissues with the carapaces removed were homogenized in $0.9 \%$ saline

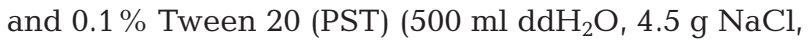
$0.5 \mathrm{ml}$ Tween 20). The homogenate was centrifuged at $3500 \times g$ for $30 \mathrm{~min}$ at $4^{\circ} \mathrm{C}$. The supernatant fluid was discarded and the pellet was resuspended in $30 \mathrm{ml}$ PST. This centrifugation was repeated once. The resulting pellet was resuspended in $5 \mathrm{ml}$ PST that was then layered on a $15 \%$ sucrose cushion. The suspension was centrifuged for $35 \mathrm{~min}$ at $2900 \times g$ at $4^{\circ} \mathrm{C}$ and the pellet was resuspended in $5 \mathrm{ml}$ PST and layered onto a $50 \%$ sucrose cushion. The suspension was again centrifuged, after which approximately $3 \mathrm{ml}$ of material was collected using a needle and syringe from the top of the sucrose cushion. The material was resuspended in $5 \mathrm{ml} \mathrm{PST}$, and centrifuged for $40 \mathrm{~min}$ at $2900 \times g$ at $4^{\circ} \mathrm{C}$. This pellet was resuspended in $5 \mathrm{ml}$ $\mathrm{TN}$ buffer (20 mM Tris- $\mathrm{HCl}, 400 \mathrm{mM} \mathrm{NaCl}$ at $\mathrm{pH} 7.5$ ) followed by purification using isopycnic centrifugation on a Renografin (Solvay Animal Health) discontinuous density gradient (14 to 21 to $28 \% \mathrm{v} / \mathrm{v}$ ) at $151200 \times g$ for $1 \mathrm{~h}$ at $4^{\circ} \mathrm{C}$. The material above the interface at the top of the $28 \%$ layer received a final wash in TN buffer with centrifugation at $52000 \times g$ for $30 \min$ at $4^{\circ} \mathrm{C}$.

The final purified pellet was resuspended in $200 \mu \mathrm{l}$ of TN buffer that was combined with $200 \mu$ lysis buffer (25 mM Tris- $\mathrm{HCl} \mathrm{pH}$ 8, 10 mM EDTA, 15\% sucrose, $2 \mathrm{mg} \mathrm{ml}^{-1}$ lysozyme) and incubated for $10 \mathrm{~min}$ at $37^{\circ} \mathrm{C}$, then $10 \mu \mathrm{l}$ of $20 \%$ SDS was added and incubated for an additional $5 \mathrm{~min}$ at $37^{\circ} \mathrm{C}$. The purified bacterial DNA was extracted twice with phenol:chloroform:isoamyl alcohol and centrifuged at $3000 \times g$ for $2 \mathrm{~min}$ at $4^{\circ} \mathrm{C}$. This extracted DNA was suspended in $500 \mu \mathrm{l}$ of $100 \%$ EtOH and placed in $\mathrm{a}-70^{\circ} \mathrm{C}$ freezer for $1 \mathrm{~h}$ and then centrifuged at $8000 \times g$ for $20 \mathrm{~min}$ at $4^{\circ} \mathrm{C}$. A final $70 \%$ ethanol wash was followed by 2 min centrifugation at $8000 \times g$ at $4^{\circ} \mathrm{C}$. The DNA pellet was air-dried and resuspended in $30 \mu \mathrm{l} 1 \times$ TE buffer $(10 \mathrm{mM}$ Tris $\mathrm{HCl}$, 1 mM EDTA, pH 8).

Bacterial isolates and DNA extractions. Five bacterial cultures (University of Arizona [UAZ]), comprising Vibrio alginolyticus, $V$. parahaemolyticus, a gram-positive coccus, a gram-positive rod and a gramnegative/oxidase-negative rod, were grown on a shaker platform at room temperature in $5 \mathrm{ml}$ tryptic soy broth (DIFCO) supplemented with $1 \% \mathrm{NaCl}$. The bacterial cultures were centrifuged at $4000 \times g$ for $3 \mathrm{~min}$ at $4^{\circ} \mathrm{C}$ and the DNA was extracted from the pellets using the Insta-Mini-Prep 3'-5' kit (5 Prime-3 Prime).

DNA was also extracted from the hepatopancreas organ (HPs) of Penaeus vannamei infected with necrotizing hepatopancreatitis (NHP) (UAZ) and a sample from specific pathogen-free (SPF) P. vannamei (Wyban 
et al. 1992) that served as the negative control for the PCR assays. The DNA extracted from these samples, using the 'High Pure PCR Template Preparation Kit' (Roche Diagnostics) and following the manufacturer's protocol, was used as the template in the PCR reactions. Using primers that amplified the 16S rRNA region of the genome $(\sim 1500 \mathrm{bp})$ and primers specific to the RLB (532 bp) the various bacterial templates tested the fidelity of the DNA and the specificity of the RLB PCR amplification.

Amplification of the 16S rRNA genes. The reaction mix for PCR contained $10 \mathrm{mM}$ PCR buffer (Tris- $\mathrm{HCl}$, $50 \mathrm{mM} \mathrm{Kcl}, \mathrm{pH}$ 8.3), $2 \mathrm{mM}$ dNTP's each, $88 \mathrm{pmol}$ of each of the 2 primers (Table 1), $2.5 \mathrm{U}$ AmpliTaq gold polymerase, $2 \mathrm{mM} \mathrm{MgCl}_{2}$ (Roche Molecular Systems), $200 \mathrm{ng}$ of purified rickettsial DNA, and sterile $\mathrm{H}_{2} \mathrm{O}$ to a $50 \mu \mathrm{l}$ volume. The thermal cycling program consisted of an initial denaturing step for $2 \mathrm{~min}$ at $95^{\circ} \mathrm{C}$, followed by 30 cycles of annealing for $30 \mathrm{~s}$ at $45^{\circ} \mathrm{C}$, extension for 2 min at $72^{\circ} \mathrm{C}$, denaturation for $30 \mathrm{~s}$ at $95^{\circ} \mathrm{C}$, ending with 1 cycle for $1 \mathrm{~min}$ at $45^{\circ} \mathrm{C}$ and $2 \mathrm{~min}$ at $72^{\circ} \mathrm{C}$. The amplified products were kept at $4^{\circ} \mathrm{C}$ at the completion of the cycling. The PCR products were run on a $0.8 \%$ agarose gel in TBE buffer (tris-borate-EDTA) containing $0.5 \mu \mathrm{g} \mathrm{ml}^{-1}$ ethidium bromide (Maniatis et al. 1982).

Sequencing of 16S rRNA PCR fragment. The PCR reaction mixture containing the amplified $\sim 1500 \mathrm{bp}$ fragment was eluted using the QIAquick PCR Purification Kit (Qiagen) by following the manufacturer's protocol. The eluted DNA concentration was determined at $260 \mathrm{~nm}$ using a BioPhotometer (Eppendorf) and was sequenced at the University of Arizona Research Laboratory DNA Sequencing Facility.

Selection of rickettsia-specific primers. Based on the sequence information, 2 oligonucleotide primers (Table 1) that recognized a $532 \mathrm{bp}$ fragment from a variable region of the 16S rRNA gene sequence were designed using the computer software program Primer Designer 4 (Scientific and Education Software). The primers were synthesized by Sigma Genosys.

PCR amplification of specific rickettsia organism. The optimized PCR reaction mixture contained $10 \mathrm{mM}$

Table 1. Sequence of PCR oligonucleotide primers, $5^{\prime}$ to $3^{\prime}$ orientation, that recognized $\sim 1500 \mathrm{bp}$ fragment from the conserved region of the 16S rRNA gene sequence (16S rRNA forward and reverse) and the $532 \mathrm{bp}$ fragment from the variable region of the 16S rRNA gene sequence (Rickettsia 2 forward and Rickettsia 5 reverse)

\begin{tabular}{|c|c|}
\hline Primer & Sequence \\
\hline 16S rRNA forward & CCG AAT TCG TCG ACA ACA GAG TTT GAT CCT GGC TCA \\
\hline 16S rRNA reverse & CCC GGG ATC CAA GCT TAC GGC TAC CTT GTT ACG ACT I \\
\hline Rickettsia 2 forward & GCG TAG GCG GAT TAG TTA GTC AGA G \\
\hline Rickettsia 5 reverse & GTT GCG CTC GTT ACA GGA CT \\
\hline
\end{tabular}

PCR buffer (Tris-HCl, $50 \mathrm{mM} \mathrm{KCl}, \mathrm{pH}$ 8.3), $1 \mathrm{mM}$ dNTP's each, $20 \mathrm{pmol}$ of each of the 2 primers (Table 1), 2.5 U AmpliTaq Gold polymerase, $2 \mathrm{mM} \mathrm{MgCl}_{2}$ (Roche Molecular Systems), $200 \mathrm{ng}$ of purified rickettsial DNA and sterile $\mathrm{H}_{2} \mathrm{O}$ in a $50 \mu \mathrm{l}$ volume. The optimized thermal cycling program consisted of an initial denaturing step for $1 \mathrm{~min}$ at $95^{\circ} \mathrm{C}$, followed by 30 cycles of annealing for $30 \mathrm{~s}$ at $60^{\circ} \mathrm{C}$, extension for $30 \mathrm{~s}$ at $72^{\circ} \mathrm{C}$, denaturation for $30 \mathrm{~s}$ at $95^{\circ} \mathrm{C}$, ending with 1 cycle for $1 \mathrm{~min}$ at $60^{\circ} \mathrm{C}$ and $2 \mathrm{~min}$ at $72^{\circ} \mathrm{C}$. The amplified PCR products were held at $4^{\circ} \mathrm{C}$ after completion of the cycling.

Cloning rickettsia-specific PCR fragment. The $532 \mathrm{bp}$ amplified PCR product was eluted from the reaction mixture using the QIAquick PCR purification kit. The eluted DNA concentration was determined using a BioPhotometer (Eppendorf). The fragment was ligated with T4 DNA ligase into the EcoRV site of the pGEMT Easy Vector System II (Promega Corporation) and transformed into competent JM109 cells following the manufacturer's protocol. The transformed bacteria were plated onto LB-amp plates, pretreated with Xgal (5-bromo-4-chloro-3-indolyl- $\beta$-D-galactoside) and IPTG (isopropyl-1-thio- $\beta$-D-galactoside) (Maniatis et al. 1982). Plates were incubated overnight at $37^{\circ} \mathrm{C}$, after which 5 white colonies were picked and grown in $5 \mathrm{ml}$ LB-amp broth. The cultures were placed on a shaker platform overnight at $37^{\circ} \mathrm{C}$, then centrifuged at $4000 \times g$ for 3 min at $4^{\circ} \mathrm{C}$ to pellet the bacteria. The pellet was resuspended in lysis buffer and the DNA was extracted using the Insta-Mini-Prep 3'-5' kit (5 Prime-3 Prime, Inc.). The cloned DNA was amplified by PCR using the rickettsia-specific primers and the described thermal cycling program.

In situ hybridization assay development. The cloned DNA fragment was labeled with digoxigenin (DIG)-11 dUTP by PCR using the rickettsia-specific primers, following the manufacturer's instructions (Genius I Kit, Roche Diagnostics). The DIG-labeled probe was tested by in situ hybridization following a protocol by Poulos et al. (1994) that was modified to accommodate bacteria. After the slides had been deparaffinized, the sections were overlaid with $100 \mu \mathrm{g} \mathrm{ml}^{-1}$ of freshly prepared lysozyme in TNE buffer (Tris, $\mathrm{NaCl}, \mathrm{EDTA}$ ), and incubated at room temperature for 15 min. The overnight hybridization with the DIG-labeled probe was done in a humid chamber at $65^{\circ} \mathrm{C}$ to increase the stringency of the assay. A coverslip on the slide prevented evaporation from occurring overnight. Afterwards, the $1 \times$ SSC (standard saline citrate) and $0.5 \times$ SSC washes were performed at $65^{\circ} \mathrm{C}$ while the incubations with the blocking buffer and the alka- 
line phosphatase labeled anti-DIG antibody were carried out at $37^{\circ} \mathrm{C}$. Final development was performed at room temperature with the reagents nitrobluetetrazolium and bromochloroindoyl phosphate in $\mathrm{pH} 9.0$ buffer.

In situ hybridization samples. In situ hybridization assays were used to detect the RLB in Penaeus monodon from the Madagascar epizootic and in experimentally induced laboratory infections of $P$. vannamei. In addition, other shrimp tissues infected with the NHP agent (Frelier et al. 1992), an unidentified shrimp micrococcus (UAZ: origin Madagascar), vibrio (UAZ: origin Mexico) and rickettsial organisms from P. monodon cultured in Malaysia (Anderson et al. 1987) and Australia (UAZ: origin Australia) were tested to validate the specificity of the probe. An SPF sample was included in each in situ assay as the negative control.

\section{RESULTS}

\section{Identification of pathogen}

Histological examination of samples from moribund Penaeus monodon preserved in Davidson's fixative revealed infection by a rickettsia-like bacteria (RLB). The appearance of infected cells varied according to tissue type. The cytoplasm of the endothelial cells, the stromal matrix cells of the lymphoid organ (LO) tubule walls, and connective tissue bordering the interstitial sinuses typically contained pale, basophilic (with H\&E) granular-like masses ranging in size from small, discrete cytoplasmic bodies to large masses filling the entire cytoplasm (Fig. 1C,D). High magnification revealed the cytoplasmic masses to be composed of tiny bacterial rods of $\sim 0.5$ to $\sim 1 \mu \mathrm{m}$ in size that stained gram-negative with the Gram-Twort stain (Fig. 1E,F).

The principal target tissues affected by this bacteria were, in order of severity, the LO, connective tissue (systemically), circulating hemocytes, fixed phagocytes, and cuticular epithelial cells. This organism did not infect the mucosal epithelium cells of the midgut, anterior midgut cecum or hepatopancreas (HP). As observed in the LO, the degree of infection of the various target tissues seemed somewhat variable. In tissues such as the sub-epithelial connective tissues of the anterior midgut cecum, the cytoplasm of some infected cells was filled with the organism, while the cytoplasm of adjacent cells contained far fewer bacteria (Fig. 1A,B). In cells with lower infection loads, the rod-shaped morphology of the bacteria was most readily apparent (Fig. 1B).

Ultrastructure examination of infected LO cells revealed that the RLB appeared to be free in the cyto- plasm rather than contained in membrane-bound inclusions (Fig. 2A). The bacteria were uniform in rod-shaped appearance, differing slightly in length, with a mean diameter of $0.45 \mu \mathrm{m}(\mathrm{n}=54$; range 0.42 to $0.54 \mu \mathrm{m})$ and a length of $1.5 \mu \mathrm{m}(\mathrm{n}=21$; range 1.3 to $2.1 \mu \mathrm{m}$ ). The bacterial cells contained poorly differentiated electron-dense and electron-lucent regions in the protoplasm that contained the chromsomal fibers of the nucleoid. The cells were bound by a cell envelope that consisted of an inner membrane, a periplasmic space, and an outer undulant membrane (Fig. 2C,D). Numerous, generally spherical, vesicles with a mean diameter of $0.085 \mu \mathrm{m}(\mathrm{n}=10$; range 0.04 to $0.13 \mu \mathrm{m})$ were present in the host cell cytoplasm and closely associated with the bacterial cells. Frequently these vesicles were observed in direct contact with the outer membrane of the bacterial cell walls, with no direct connection (Fig. 2C,D). Early stages of RLB cell division (Fig. 2B,D) were suggested in bacterial cells of lengths $>1 \mu \mathrm{m}$ by constrictions near the mid section. In Fig. 2C, 2 daughter cells are still attached by the outer cell membrane.

\section{PCR amplification}

DNA extracted from the hepatopancreas organs (HPs) of RLB-infected Penaeus monodon was amplified by PCR using both the bacterial and rickettsiaspecific primer pairs. Additional DNA templates from negative control SPF shrimp, NHP-infected shrimp and 5 bacterial samples grown from culture (UAZ) were assayed by PCR. Except for the SPF DNA, PCR amplification occurred in all of the samples tested using the bacterial primer pair, which was visualized on the $1.5 \%$ agarose gel as a $1500 \mathrm{bp}$ fragment (Fig. 3). The only sample amplified by the rickettsia-specific primer pair (532 bp fragment) was the DNA from the RLB sample. Using the optimized thermal cycling conditions, the rickettsia-specific primer pair did not amplify any of the other DNA templates from the bacteria assayed, nor the DNA template from the SPF sample (Fig. 3).

\section{In situ hybridization assays}

The DNA probe demonstrated a positive hybridization signal in the natural and experimentally induced RLB infections (Fig. 4), but failed to hybridize with the SPF samples or any of the specimens with other types of bacterial infections.

The target tissues for the RLB were more clearly elucidated by the hybridization assays, showing strong positive signals only in tissues of mesodermal 

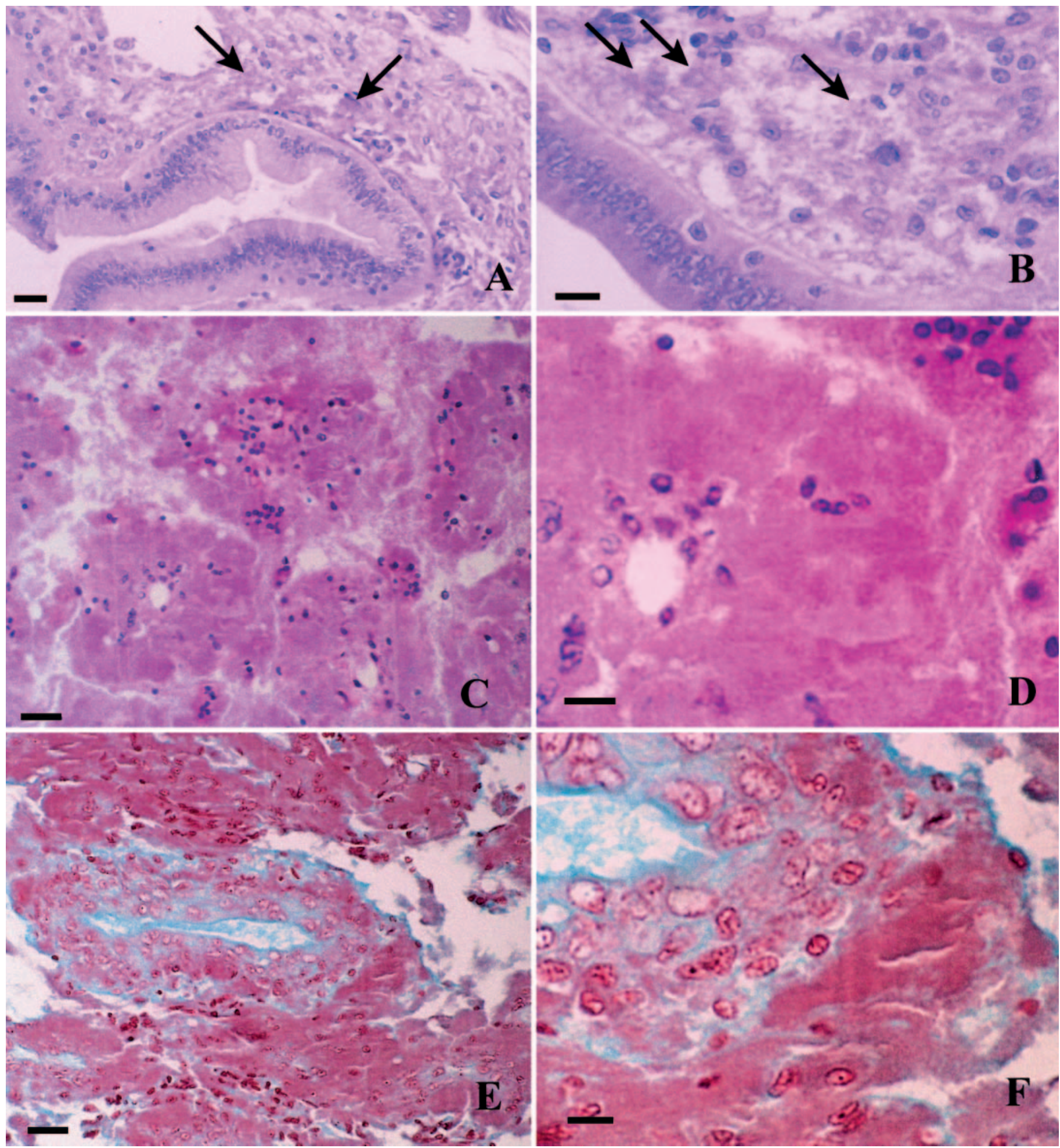

Fig. 1. Penaeus monodon. Histological sections of Davidson's fixed tissues from infected shrimp with a rickettsia-like bacterium (RLB). (A, B) Sections through a portion of the anterior midgut cecum. The RLB is apparent as bluish-gray masses (arrows) in the cytoplasm of the subcuticular and serosal connective tissue cells of the cecum; H\&E. (C-F) H\&E and Gram-stained consecutive sections of the lymphoid organ (LO) of a shrimp with advanced infection by RLB, which are visible in the H\&E-stained sections (C and D) as pale, basophilic grainy masses of bacteria that fill the cytoplasm of every LO stromal matrix cell shown; the RLB are gram-negative in (E) and (F). H\&E and Gram-Twort stains; Scale bars in $A, C, E=20 \mu \mathrm{m}$, in $B, D, F=10 \mu \mathrm{m}$ 

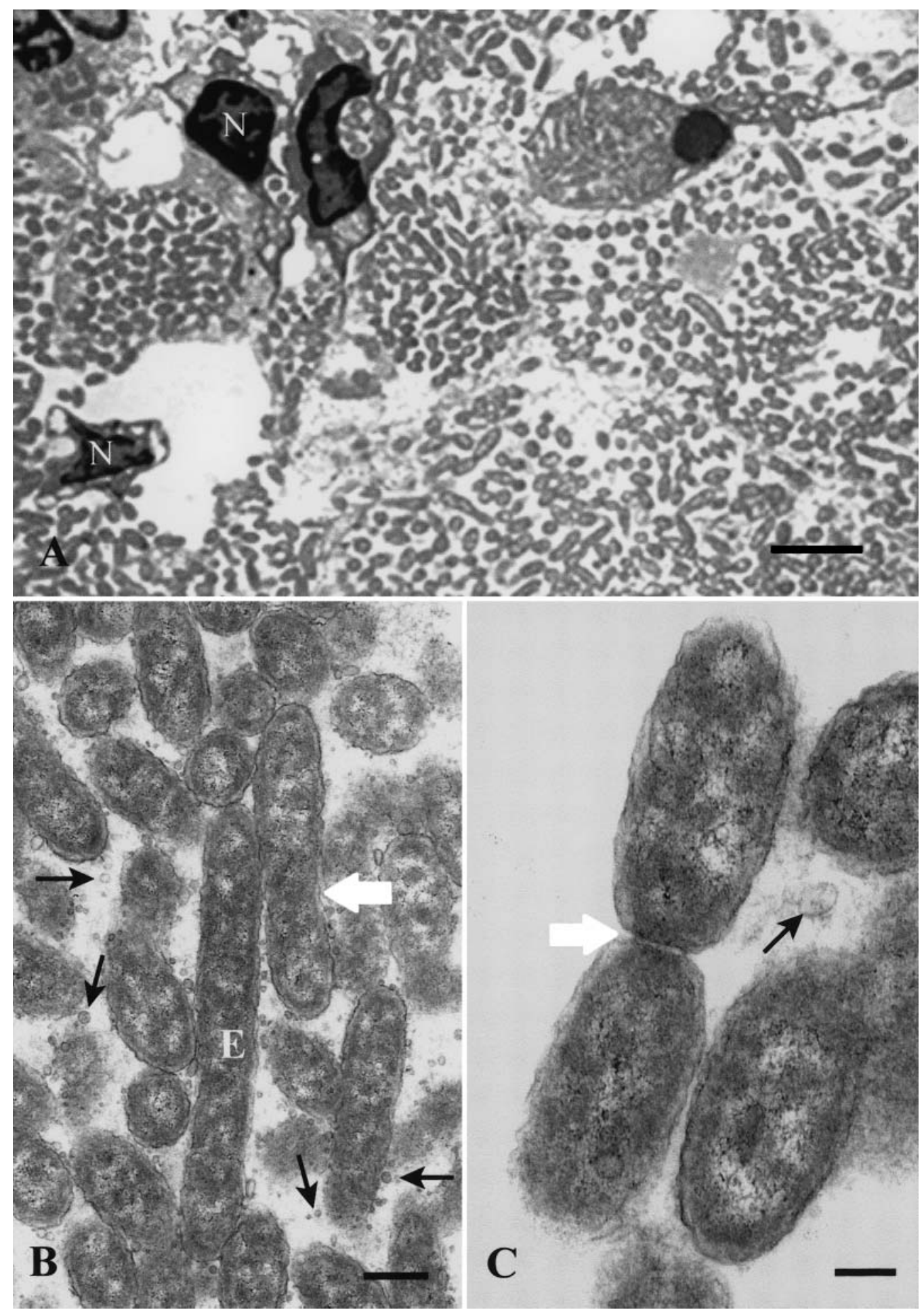

Fig. 2. Penaeus monodon. TEM of rickettsia-like bacterium (RLB) in lymphoid organ (LO) stromal matrix cells. (A) Low magnification of several LO cells in which the cytoplasm is filled with the RLB, which appear to be free in the cytoplasm rather than contained in a membrane bound cytoplasmic inclusion $(\mathrm{N}=$ nuclei; scale bar $=2.6 \mu \mathrm{m})$. (B) Higher magnification of RLB in the cytoplasm of an LO stromal matrix cell showing a markedly elongated (E) RLB, and another with a mid-level constriction (white arrow) suggestive of cell division, also shown are numerous profiles of generally spherical $0.085 \mu$ m-diameter vesicles (black arrows) that are closely associated with the outer membrane of the RLB (scale bar $=0.48 \mu \mathrm{m}$ ). (C) Two daughter bacterial cells that have remained connected by their apical surfaces to the outer cell wall membrane (white arrow); a spherical vesicle (black arrow) is shown in association with an RLB (scale bar $=0.20 \mu \mathrm{m}$ ) 
Fig. 3. Electrophoretic patterns in a $1 \%$ agarose gel using the bacterial 16S rRNA primers (left) and the rickettsia-specific primers (right): M: $1 \mathrm{~kb}$ marker; 1: Vibrio alginolyticus; 2 : $V$. parahaemolyticus; 3: Gram-positive coccus; 4: Gram-positive rod; 5: Gram-negative rod; 6: necrotizing hepatopancreatitis (NHP); 7: rickettsialike bacterium; 8: specific pathogen-free $\left(\mathrm{SPF}_{\text {; }}\right.$ negative control)

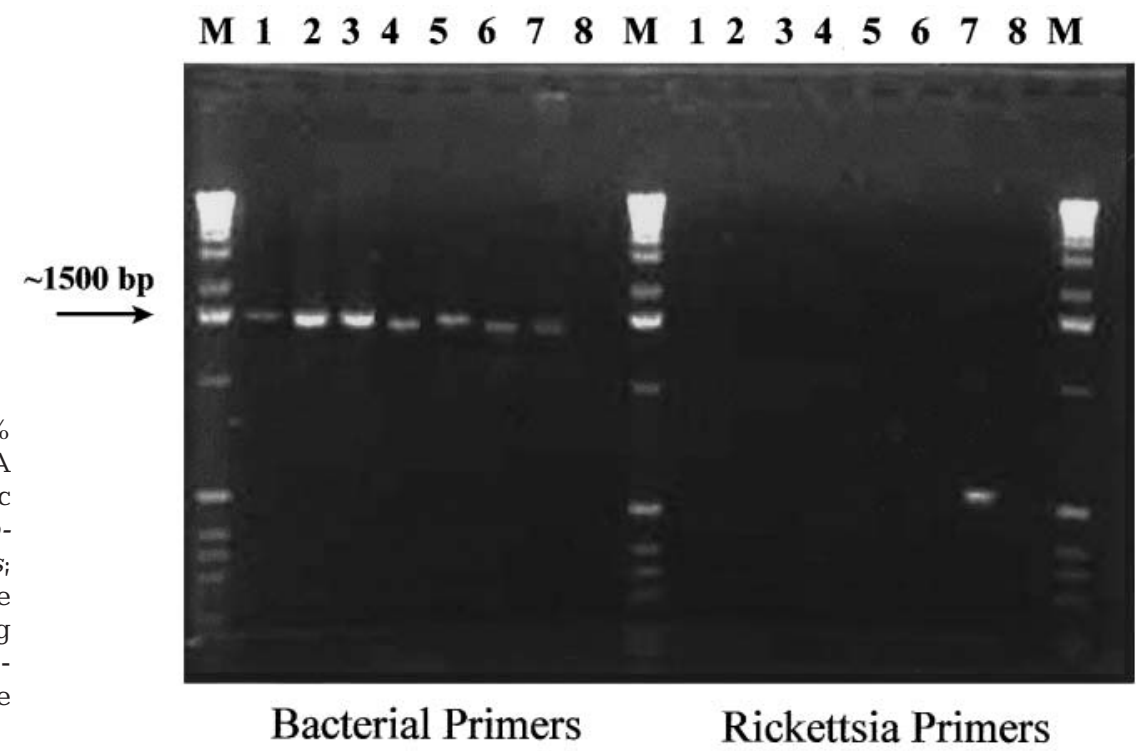

origin. The order of severity was similar to that observed by histological examination. The LO was typically the most severely affected tissue in natural infections (Fig. 4B), then connective tissue cells of the gastrointestinal tract, followed by the subcuticular connective tissues of the cuticular epithelium, and finally other organs and tissues. Also presenting strong probe signals were the gills and heart (presumed to be due to infected connective tissue cells, fixed phagocytes and hemocytes). The epithelial cells of the hepatopancreatic tubules, the midgut mucosa, the midgut cecal epithelium, the general cuticular epithelium, the foregut cuticular epithelium, and the antennal gland tubules did not appear to be infected by the RLB. Focal areas of probe signal were also present in the striated muscles, cardiac muscle, the hematopoietic nodules, nerve ganglia, and nerve fibers, apparently due to the presence of infected connective tissue cells or hemocytes in these tissues, but generally these tissue types were not infected. Whether the RLB infects gonadal tissues could not be determined, because the shrimp in these studies were generally small juveniles.

\section{DISCUSSION}

The severity of infection, as evidenced from histological examination, suggests that the intracellular rickettsia-like bacterium (RLB) was the cause of disease and resultant mortalities in the samples of Penaeus monodon from Madagascar. Laboratory transmission of the bacterium to $P$. vannamei resulting in lethal laboratory infections also documents the pathogenicity of this organism. The bacterium is tentatively characterized as a rickettsia or RLB based upon its size and morphology, cytoplasmic location and Gram stain reaction.

Development of the PCR and the in situ hybridization digoxigenin-labeled probe for detection of the presence of the RLB were contingent upon the sequencing of the 16S rRNA gene. Due to the conserved nature of this gene in all bacteria, optimization of the PCR cycling parameters, with special emphasis on temperatures, was a critical step in achieving specificity of the PCR assay. In situ hybridization specificity was achieved by increasing the hybridization temperature to $65^{\circ} \mathrm{C}$. At temperatures lower than $60^{\circ} \mathrm{C}$, crossreactivity was observed with the necrotizing hepatopancreatitis (NHP) and Vibrio sp. specimens. Limiting the specificity of the probe for the RLB was accomplished by increasing the hybridization temperature and the stringency of the assay.

Further studies on this bacterium are needed to properly classify this organism. Comparison of the $16 \mathrm{~S}$ rRNA sequence to other sequences from the same gene in other bacteria will be analyzed and placed in a phylogenic tree. Field testing of the molecular diagnostic procedures developed in this study will be an ongoing project, as samples become available, to further validate the specificity and potential utility of these techniques.

Acknowledgements. Funding for this research was provided by a grant from the USMSFP, USDA, CREES, Grant No. 9938808-7431, and from a US National Fisheries Institute Grant. The authors would like to thank Leone Mohney, Brenda White-Nobel and Dr. Carlos Pantoja for their input and/or assistance in conducting these experiments. 

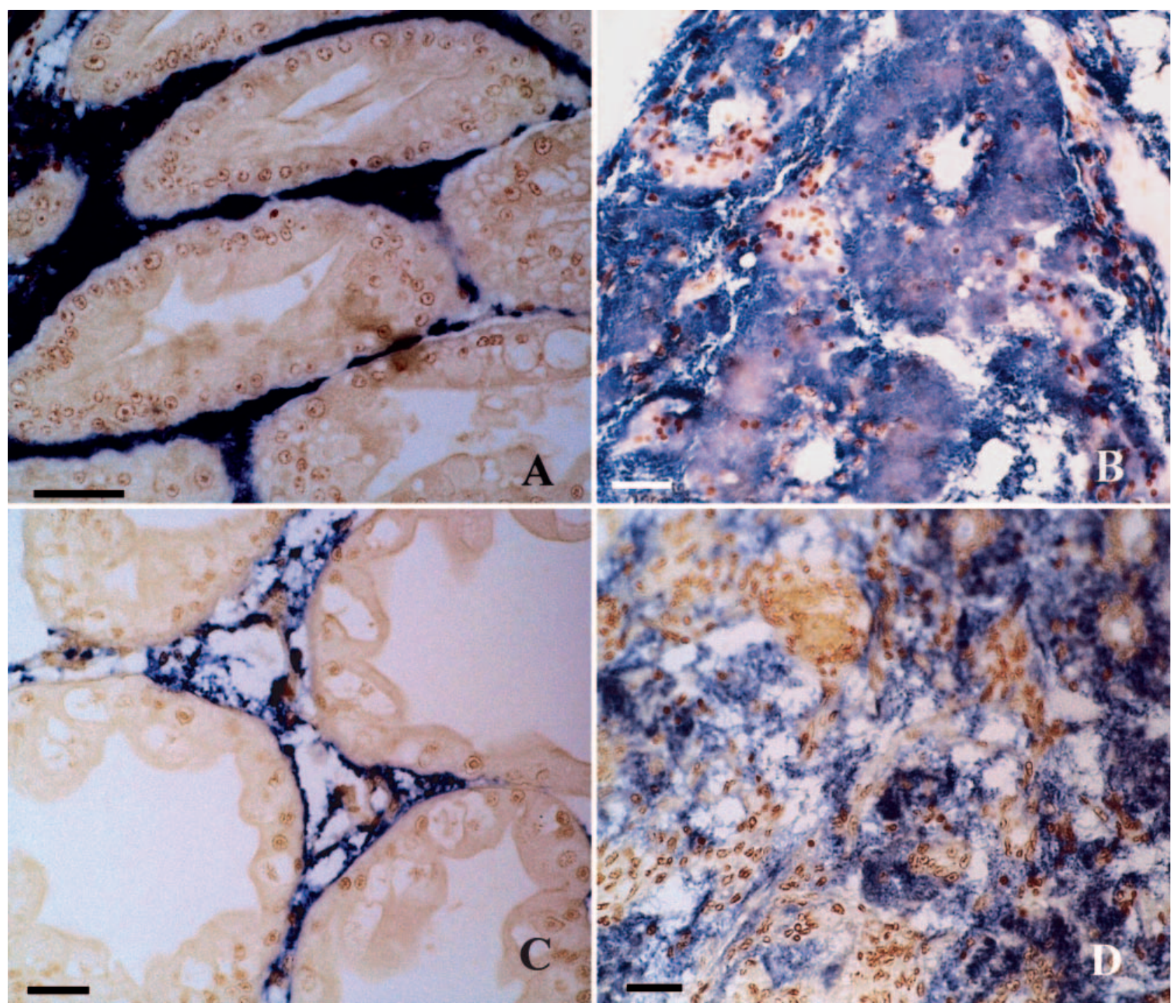

Fig. 4. Sections of an RLB-infected hepatopancreas (HP) and lymphoid organ (LO) reacted by in situ hybridization with a DIGlabeled DNA probe to the bacterium. (A, B) HP (A) and LO (B) originating from a natural RLB infection in Penaeus monodon showing positive hybridization signal, visualized with the dark blue/purple precipitate; $(C, D)$ intertubular connective tissues of the HP (C) and LO (D) stomal matrix cells from shrimp experimentally infected with RLB showing positive hybridization signal. Scale bars $=20 \mu \mathrm{m}$

\section{LITERATURE CITED}

Anderson I, Shariff M, Nash G, Nash M (1987) Mortalities of juvenile shrimp Penaeus monodon, associated with Penaeus monodon baculovirus, cytoplasmic reo-like virus, and rickettsial and bacterial infections, from Malaysian brackishwater ponds. Asian Fish Sci 1:47-64

Bell TA, Lightner DV (1988) A handbook of normal penaeid shrimp histology. World Aquaculture Society, Baton Rouge, LA

Bonami JR, Pappalardo R (1980) Rickettsial infection in marine crustacea. Experientia 36:180-181

Bower SM, Meyer GR, Boutillier JA (1996) Stained prawn disease (SPD) of Pandalus platyceros in British Columbia, Canada, caused by a rickettsial infection. Dis Aquat Org $24: 41-54$
Brock JA, Nakagawa LK, Hayashi T, Teruya S, van Campen $\mathrm{H}$ (1986) Hepatopancreatic rickettsial infection of penaeid shrimp, Penaeus marginatus (Randall), from Hawaii. J Fish Dis 9:73-77

Edgerton BF, Prior HC (1999) Description of a hepatopancreatic rickettsia-like organism in the redclaw crayfish Cherax quadricarinatus. Dis Aquat Org 36:77-80

Federici BA, Hazard EI, Anthony DW (1974) Rickettsia-like organism causing disease in a crangonid amphipod from Florida. Appl Microbiol 28:885-886

Frelier PF, Sis RF, Bell TA, Lewis DH (1992) Microscopic and ultrastructural studies of necrotizing hepatopancreatitis in Pacific white shrimp (Penaeus vannamei) cultured in Texas. Vet Pathol 29:269-277

Frutos R, Federici B, Revet B, Bergoin M (1994) Taxonomic studies of rickettsiella, rickettsia and chlamydia using 
genomic DNA. J Invertebr Pathol 63:294-300

Fryer JL, Lannan CN (1994) Rickettsial and chlamydial infections of freshwater and marine fishes, bivalves and crustaceans. Zool Stud 33:95-107

Harshbarger JC, Chang SC, Otto SV (1977) Chlamydiae (with phages), mycoplasmas, and rickettsiae in Chesapeake Bay Bivalves. Science 196:666-668

Holthuis LB (1980) FAO species catalog, Vol. 1. Shrimp and prawn of the world. FAO Fish Synop 125. FAO, Rome

Jimenez R, Romero X (1997) Infection by intracellular bacterium in red claw crayfish, Cherax quadricarinatus (von Martens) in Ecuador. Aquac Res 28:923-929

Johnson PT (1984) A rickettsia of the blue king crab, Paralithodes platypus. J Invertebr Pathol 44:112-113

Krol RM, Hawkins WE, Overstreet RM (1991) Rickettsial and mollicute infections in hepatopancreatic cells of cultured Pacific white shrimp (Penaeus vannamei). J Invertebr Pathol 57:362-370

Larrson R (1982) A rickettsial pathogen of the amphipod Rivulogammarus pulex. J Invertebr Pathol 40:28-35

Lightner DV (1996) A handbook of shrimp pathology and diagnostic procedures for diseases of cultured penaeid shrimp. World Aquaculture Society, Baton Rouge, LA

Maniatis T, Fritsch EF, Sambrook J (1982) Molecular cloning:

Editorial responsibility: Timothy Flegel,

Bangkok, Thailand a laboratory manual. Cold Spring Harbor Laboratory, Cold Spring Harbor, NY

Ollett WS (1947) A method for staining both Gram positive and Gram negative bacteria in sections. J Pathol Bacteriol 59:357-358

Poulos BT, Mari J, Bonami JR, Redman R, Lightner DV (1994) Use of non-radioactively labeled DNA probes for the detection of a baculovirus from Penaeus monodon by in situ hybridization on fixed tissue. J Virol Methods 49:187-194

Tan CK, Owens L (2000) Infectivity, transmission and 16S rRNA sequencing of a rickettsia, Coxiella cheraxi sp. nov., from the freshwater crayfish Cherax quadrucarinatus. Dis Aquat Org 41:115-122

Wang W, Gu Z (2002) Rickettsia-like organism associated with tremor disease and mortality of the Chinese mitten crab Eriocheir sinensis. Dis Aquat Org 48:149-153

Winkler HH (1990) Rickettsia species (as organisms). Annu Rev Microbiol 44:131-153

Wyban JA, Swingle JS, Sweeny JN, Pruder GD (1992) Development and commercial performance of high health shrimp using specific pathogen free (SPF) broodstock Penaeus vannamei. In: Wyabn J (ed) Proc Specific Session on Shrimp Farming. World Aquaculture Society, Baton Rouge, LA, p 254-260

Submitted: May 29, 2002; Accepted: August 2, 2002 Proofs received from author(s): December 18, 2002 